\title{
TINJAUAN HUKUM ISLAM TENTANG CAMPUR TANGAN MANUSIA DALAM UZUR SYARA' (STUDI RUKHSHAH PADA PEREMPUAN)
}

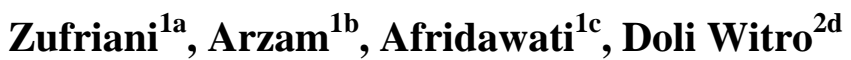 \\ ${ }^{1}$ Institut Agama Islam Negeri Kerinci \\ ${ }^{2}$ UIN Sunan Gunung Djati Bandung \\ a zufrianistainkerinci@gmail.com, ${ }^{\mathrm{b}}$ arzam@iainkerinci.ac.id, ${ }^{\mathrm{c}}$ afridawati.133@gmail.com, \\ doliwitro01@gmail.com
}

\section{Abstrak}

Allah s.w.t. memberikan rukhshah (keringanan atau kemudahan) bagi perempuan atas segala uzur yang dialaminya. Haid, hamil, nifas dan menyusukan anak bagi seorang perempuan termasuk uzur (halangan) syara'. Uzur syara' itu yang pada dasarnya merupakan hak dan urusan Allah s.w.t., tetapi zaman sekarang manusia seolah-olah telah dapat mencampuri masalah uzur ini. Dikarenakan manusia telah mencampuri masalah ini, maka uzur samawi tersebut dapat berubah menjadi uzur muktasabi (halangan yang diusahakan oleh manusia). Campur tangan yang dimaksud seperti menciptakan obat-obatan dan alat-alat yang dapat mengatur jalannya suatu uzur syara', seperti membuat obat atau pil anti haid. Artikel ini membahas tinjauan hukum Islam tentang campur tangan manusia dalam uzur syara' yang difokuskan kepada rukhshah pada perempuan seperti dalam kasus haid, nifas atau menyusui, dan juga pada kasus saat melaksanakan ibadah haji. Artikel ini bertujuan tujuan untuk mengetahui hukum campur tangan manusia dalam uzur syara' khusus pada kasus penggunaan pil haid oleh perempuan. Artikel ini menggunakan penelitian kualitatif yang bersifat kajian pustaka. Teknik analisis data yang digunakan adalah kondensasi data, penyajian data, dan penarikan kesimpulan. Hasil analisis menunjukkan hukum bagi wanita yang menggunakan pil anti haid sangat erat hubungannya dengan niat. Sedangkan niat itu sendiri terletak di dalam hati, sehingga akan sulit untuk diketahui. Secara tidak langsung dapat diketahui sebahagian dari niat seorang perempuan dalam menggunakan obat-obat anti haid adalah untuk maksimalkan ibadahnya.

Kata Kunci: Hukum Islam, Campur Tangan Manusia, 'Uzur Syara', Rukhshah Perempuan

\begin{abstract}
Allah s.w.t. provide rukhshah (relief or ease) for women for all the aging they experience. Menstruation, pregnancy, childbirth, and breastfeeding for a woman are included in the syara' age (barrier). The syara' age is the right and business of Allah s.w.t., but nowadays, humans seem to have been able to interfere with this aging problem. Because humans have interfered in this matter, the samawi age can turn into the muktasabi age (obstacles attempted by humans). The intervention in question is like creating medicines and tools that can regulate the course of a syara' age, such as making anti-menstrual drugs or pills. This article discusses a review of Islamic law regarding human intervention in syara' age, which focuses on rukhshah on women, such as in cases of menstruation, childbirth or breastfeeding, and in cases when carrying out the pilgrimage. This article aims to find out the law of human intervention in the age of syara' specifically in cases of using menstrual pills by women. This article uses qualitative research that is the literature review. Data analysis techniques used are data condensation, data presentation, and drawing conclusions. The analysis results show that the law for women who use anti-menstrual pills is very closely related to intention. While the definition itself lies in the heart, so it will be challenging to know. Indirectly, it can be seen that part of a woman's intention in using anti-menstrual drugs is to maximize her worship.
\end{abstract}

Keywords: Islamic Law, Human Intervention, 'Uzur Syara', Women's Rukhshah 


\section{A. Pendahuluan}

Ibadah merupakan puncak ketundukan manusia kepada Allah s.w.t akibat adanya rasa untuk mengagungkan terhadap yang disembah dan kekuasaanNya yang Maha Tinggi. Oleh sebab itu, pada prinsipnya ibadah ini merupakan pemenuhan kebutuhan rohani di dalam diri manusia dan menanamkan keyakinan bahwa setelah kehidupan di dunia ini berakhir, masih ada lagi kehidupan selanjutnya yang bersifat abadi $^{1}$, yaitu kehidupan di akhirat.

Umat Islam pada umumnya, dan para wanita muslimah khususnya yang menyadari akan tugas dan tujuan hidup tersebut, kadang-kadang merasakan sangat minim dalam melaksanakan ibadah, padahal sebagian dari mereka kadangkadang sangat berkeinginan untuk melaksanakan ibadah-ibadah sebanyak mungkin dan semaksimal mungkin, tetapi terhalang dengan suatu uzur yang dialaminya, sehingga mereka tidak dapat melaksanakan ibadah tersebut.

Sebagaimana yang telah diketahui bahwa bagi seorang perempuan yang sedang mengalami haid atau nifas tidak dibenarkan melakukan puasa, shalat atau haji, karena haid dan nifas merupakan uzur syara' yang menghalangi melakukan ibadah tersebut. Perempuan tidak diperbolehkan masuk ke tempat ibadah. ${ }^{2}$ Meskipun di sisi lain ada juga yang berpendapat diboleh jika mampu menjaga darah haid tidak jatuh ke lantai. ${ }^{3}$

Mendirikan shalat dan puasa merupakan kewajiban bagi setiap individu umat Islam; apabila seseorang tidak melaksanakannya, maka seseorang akan

1 Ismail Muhammad Syah dkk., Filsafat Hukum Islam (Jakarta: Bumi Aksara, 1992), 7.

2 Ali Sodiqin, "Fiqh Sains: Elaborasi Konsep 'Illat Menuju Pembentukan Hukum Islam Yang Aktual," Al-Mazaahib (Jurnal Perbandingan Hukum) 1, no. 1 (2012): 1-16, http://ejournal.uinsuka.ac.id/syariah/almazahib/article/view/1338.

${ }^{3}$ Abd. Rouf, "Model Ijtihad Ulama Di Era Modern," Sakina: Journal of Family Studies 3, no. 1 (2019): 1-12, http://urj.uinmalang.ac.id/index.php/jfs/article/view/428. mendapat dosa. Kewajiban yang harus dilakukan oleh setiap individu menurut istilah agama disebut fardhu 'ain (kewajiban bagi setiap individu). Dari satu sisi, umat Islam yang betul-betul mengetahui dan memahami ketentuan ajaran agama akan selalu berlomba untuk mencari keredhaan Allah, mereka akan selalu memperbanyak amal shaleh sebagai bekal menuju kebahagiaaan hidup di akhirat kelak, karena kehidupan di dunia bersifat sementara, sedangkan kehidupan di akhirat merupakan kehidupan yang kekal.

Bibit-bibit kebahagiaan hidup di akhirat disemai dan ditanam sewaktu hidup di dunia ini; semakin baik bibit yang ditanam serta ditanam pula pada lahan yang subur, maka diperkirakan hasil yang akan diterima nantinya akan menjadi baik. Dengan kata lain, semakin baik dan semakin banyak amal ibadah yang dilakukan oleh seseorang di dunia ini, diharapkan akan memperoleh kebahagiaan kehidupannya di akhirat.

Shalat, puasa, zakat dan haji merupakan pokok-pokok ibadah sebagaimana termuat dalam Islam. Namun cabang-cabangnya banyak sekali, bahkan semua perbuatan yang baik dan dilakukan niat yang baik semuanya termasuk ibadah, karena kabaikan sekecil apapun akan mendapat pahala dari Allah s.w.t., sebaliknya juga kejahatan yang dilakukan sekecil apapun pasti akan mendapat dosa sebagaimana Allah berfirman:

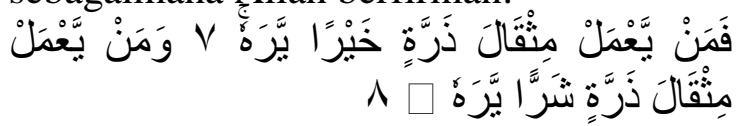

Maka barangsiapa mengerjakan kebaikan seberat zarrah, niscaya dia akan melihat (balasan)nya, dan barangsiapa mengerjakan kejahatan seberat zarrah, niscaya dia akan melihat (balasan)nya. (Q.S. AlZalzalah: 7-8)

Dari ayat di atas, dapat dipetik suatu makna bahwa untuk memperoleh ridha Allah dan kebahagian hidup di akhirat, maka seseorang harus memperbanyak 
amal kebajikan selam hidup di dunia. Secara lahiriah, kesempatan untuk memperbanyak amal ibadah itu terbuka bagi kaum laki-laki, sementara bagi kaum perempuan tidak memiliki kesempatan secara penuh. Hal ini disebabkan banyaknya uzur yang dialaminya, seperti haid, nifas, hamil, dan menyusui. Di saat sedang mengalami haid dan nifas mereka tidak dibenarkan melaksanakan shalat, puasa, menyentuh dan membaca AlQur'an dan lain-lain, sedangkan di saat hamil tua dan menyusui anaknya mereka diperbolehkan untuk tidak melakukan ibadah puasa ramadhan.

Perempuan yang merasa terlalu sedikit kesempatan untuk melakukan ibadah, sedangkan mereka berkeinginan juga untuk memiliki kesempatan seperti laki-laki, sehingga sebagian dari mereka mungkin merasa rugi kalau meninggalkan ibadah-ibadah tersebut. Namun dibalik semuanya itu, Allah s.w.t. memberikan rukhshah (keringanan atau kemudahan) ${ }^{4}$ bagi perempuan atas segala uzur yang dialaminya, karena uzur (halangan) yang dialaminya berupa haid tersebut merupakan uzur samawi, yang pada dasarnya bukan usaha dari manusia, melainkan sudah menjadi fitrah yang ditentukan Allah untuk kaum perempuan.

Meskipun secara lahiriah perempuan itu sedikit sekali kesempatan melakukan ibadah, namun secara batiniah mereka mempunyai kesempatan yang sama dengan laki-laki, karena apabila mereka tidak melaksanakan shalat atau puasa di saat mengalami haid atau nifas, berarti mereka telah berbuat taat dan patuh kepada ketentuan Allah dan Rasul yang mengharamkan mereka melakukan ibadahibadah tersebut. Artinya, dengan tidak melaksanakan shalat dan puasa bagi wanita yang sedang haid dan nifas mereka akan mendapat pahala. Sebaliknya, apabila mereka memaksakan diri untuk

${ }^{4}$ Sulastri Caniago, “Azimah Dan Rukhshah Suatu Kajian Dalam Hukum Islam," Juris 13, no. 2 (2014):

116 , https://doi.org/10.1234/juris.v13i2.1137. melaksanakan shalat dan puasa pada saat mengalami uzur justru mereka akan mendapat dosa. Oleh karena itu, dapat dikatakan bahwa tidak melaksanakan ibadah shalat atau puasa bagi wanita yang sedang haid dan nifas, justru itulah yang disebut dengan ibadah bagi mereka, karena pada saat itu mereka dilarang melaksanakannya.

Haid, hamil, nifas dan menyusukan anak bagi seorang perempuan termasuk uzur (halangan) syara'. Uzur syara' itu yang pada dasarnya merupakan hak dan urusan Allah s.w.t., tetapi zaman sekarang manusia seolah-olah telah dapat mencampuri masalah uzur ini. Dikarenakan manusia telah mencampuri masalah ini, maka uzur samawi tersebut dapat berubah menjadi uzur muktasabi (halangan yang diusahakan oleh manusia). Campur tangan yang dimaksud seperti menciptakan obat-obatan dan alat-alat yang dapat mengatur jalannya suatu uzur syara', seperti membuat obat atau pil anti haid.

Artikel ini membahas tinjauan hukum Islam tentang campur tangan manusia dalam uzur syara' yang difokuskan kepada rukhshah pada perempuan seperti dalam kasus haid, nifas atau menyusui, dan juga pada kasus saat melaksanakan ibadah haji. Artikel ini bertujuan tujuan untuk mengetahui hukum campur tangan manusia dalam uzur syara' khusus pada kasus penggunaan pil haid oleh perempuan.

\section{B. Metode Penelitian}

Artikel ini menggunakan penelitian kualitatif yang bersifat kajian pustaka. Data-data dalam artikel ini berasal dari sumber yang bersifat pustaka. Sumbersumber tersebut berupa buku, artikel ilmiah, dan sumber pustaka lain yang mendukung permasalahan yang tengah dikaji yaitu tentang keadaan uzur, perubahan illat hukum, haid, dan nifas. Data-data diperoleh dengan membaca, memahami, dan menganalisis bahan pustaka yang telah dikumpulkan. Data- 
data dalam artikel ini disajikan dengan cara naratif-deskriptif. Teknik analisis data yang digunakan adalah kondensasi data, penyajian data, dan penarikan kesimpulan. ${ }^{5}$

\section{Hasil dan Pembahasan \\ Keadaan Uzur Syara' pada Perempuan}

Kemajuan ilmu pengetahuan dan teknologi dewasa ini yang semakin pesat; manusia telah mampu mengatur dan menundukkan sebagian dari isi bumi ini. Apabila dulunya masih terlalu banyak rahasia yang terselubung di alam ini, tetapi ilmu pengetahuan dan teknologi secara berangsur-angsur telah dapat menyingkap tabir rahasia tersebut. Memang kenyataannya, banyak yang telah dilakukan manusia dalam menyingkap tabir rahasia yang selama ini masih terselubung itu, dan kemampuan ilmu pengetahuan manusia akan terus berkembang, sehingga tidak menutup kemungkinan akan banyak lagi rahasiarahasia yang dapat diungkapkan oleh manusia di masa-masa yang akan datang.

Di antara kemajuan yang telah dapat dicapai oleh manusia ialah mereka telah dapat menciptakan obat-obatan dan alatalat yang dapat mengatur jalannya suatu uzur syara', seperti membuat obat atau pil anti haid. Dengan dibuatnya obat anti haid, berarti seseorang perempuan telah dapat mengatur sendiri tentang uzurnya; apakah ia menghendaki datangnya haid atau tidak.

Di samping itu, teknologi juga sudah menciptakan alat yang dapat mengatur kehamilan, mengatur kelahiran, sehingga seorang perempuan atau suatu keluarga sudah dapat pula mengaturnya, apakah ia menginginkan suatu kehamilan atau tidak. Andaikata mereka memutuskan untuk tidak hamil dan tidak melahirkan, berarti tidak akan ada lagi kehamilan atau kelahiran dari perempuan tersebut. Akibatnya, nifas yang termasuk juga uzur

${ }^{5}$ Matthew B. Miles, A. Michael Huberman, and Johnny Saldaña, Qualitative Data Analysis: A Methods Sourcebook (California: SAGE Publications, Inc., 2014). syara' tidak akan pernah ada. Dan kadangkadang terjadi pula bagi seseorang perempuan yang sudah melahirkan, tetapi ia tidak berniat menyusukan anaknya. Keadaan ini terjadi disebabkan telah banyaknya persediaan susu kaleng, sehingga mereka memberikan susu kaleng tersebut kepada bayinya, padahal menyusukan anak termasuk uzur melaksanakan puasa ramadhan.

Pada saat seorang perempuan atau manusia mengalami uzur, kepadanya diperbolehkan oleh syara' menunda atau tidak melaksanakan kewajiban menurut waktu yang telah ditentukan; kebolehan dari syara' ini merupakan keringanan atau rukhshah yang diberikan kepada manusia. Berbicara dalam masalah uzur (halangan) syara' maka perempuan yang banyak menerimanya. Sebab, merekalah yang paling banyak mengalami uzur tersebut dan mereka pula yang paling banyak menerima rukhshah. Tetapi apabila penyebab untuk mendapatkan rukhshah itu sudah dikurangi atau dihilangkan, maka dengan sendirinya keringanan yang seharusnya diterima akan hilang pula.

\section{Perubahan Illat Merubah Hukum}

Penetapan hukum dalam Islam bergantung pada illat dan perubahan hukum selalu diiringi dengan illatnya. ${ }^{6}$ Dengan kata lain bahwa selama ada illat maka akan ada hukum, tetapi bila illat tidak ada, maka hukum pun tidak akan pernah ada. ${ }^{7}$ Hukum Islam dengan segala

6 Ubaidillah Ubaidillah, “"Konspirasi Politik' Hukum Islam Di Indonesia," Mahkamah: Jurnal Kajian Hukum Islam 3, no. 2 (2018): 21926, https://doi.org/10.24235/mahkamah.v3i2.3414; Fathurahman Azhari, "Pemikiran Ulama Tentang 'Illat Hukum (Suatu Kajian Ushul Fiqh)," Jurnal Darussalam 15, no. 2 (2014): 35-52, http://idr.uinantasari.ac.id/6808/; Muchlis Bahar, "Metode Penemuan Alasan Rasional Dalam Hukum Islam (Masalik Al-'Illat)," FITRAH: Jurnal Kajian IlmuIlmu Keislaman 1, no. 1 (May 31, 2015): 177-88, https://doi.org/10.24952/fitrah.v1i1.334.

7 Romli, "'Illat Dan Pengembangan Hukum Islam," Intizar 20, no. 2 (2014): 221-46, http://jurnal.radenfatah.ac.id/index.php/intizar/articl e/view/431. 
illat hukumnya, bertujuan untuk mendatangkan kebaikan atau kemaslahatan bagi manusia; baik dalam bentuk mengambil manfaat ataupun untuk menolak suatu bahaya atau bencana. Ketergantungan hukum terhadap illat tergambar dalam suatu kaedah ushul yang menjelaskan: Hukum itu berputar bersama illatnya dalam mewujudkan dan meniadakan hukum. ${ }^{8}$

Haid dan nifas adalah uzur samawi, yaitu uzur yang datang-nya tiba-tiba dan tanpa adanya usaha manusia. Pada seorang perempuan haid menandakan bahwa dirinya sudah baligh. ${ }^{9}$ Pada saat seseorang perempuan atau manusia mengalami uzur, maka kepadanya diperbolehkan oleh syara' menunda atau tidak melaksanakan suatu ibadah menurut waktu yang telah ditentukan oleh agama :

Dari Ummu Salamah r.a. ia berkata; "Adalah wanita-wanita yang nifas di zaman Nabi SAW duduk (tidak sembahyang) sehabis melahirkan selama empat puluh hari. (Diriwayatkan oleh Imam yang lima kecuali Nasa'i, dan lafaz yang lain dalam riwayatnya: "Dan Nabi SAW tidak menyuruhnya mengqadhokan sembahyang semasa nifas dan Hakim mengesahkannya). ${ }^{10}$

Berdasarkan Hadits yang telah dikemukakan di atas jelaslah bahwa wanita-wanita yang sedang mengalami haid dan nifas diperbolehkan tidak mengerjakan shalat. Dan semua shalat yang ditinggalkan selama mengalami haid dan nifas itu tidak dituntut mengqadhokannya. Sedangkan ibadah puasa boleh tidak dikerjakan selama mengalami haid dan nifas, tetapi ia harus diqadhokan pada hari-hari yang lain sebanyak hari yang tidak dipuasakan. Hal

\footnotetext{
${ }^{8}$ Mukhtar Yahya, Dasar-Dasar Pembinaan Hukum Islam (Bandung: Al-Ma'arif, 1993), 550.

9 Noor Harisudin, Pengantar Ilmu Fiqh (Surabaya: CV. Salsabila Putra Pratama, 2019), 45.

10 Muh. Syarief Sukandy, Tarjamah Bulughul Maram (Bandung: Al-Ma'arif, 1991), 59.
}

ini telah dijelaskan oleh Aisyah dalam sebuah Hadits:

Dari Mu'azah ia berkata: Saya bertanya kepada Aisyah: "Apakah sebab perempuan yang sedang haid mengqadhokan puasa dan tidak mengqadhokan shalat?, Aisyah menjawab:" Sesungguhnya kami mengalami hal demikian sewaktu bersama Rasulullah, maka kami diwajibkan mengqahdokan puasa dan tidak diwajibkan mengqadhokan shalat. $^{11}$ (H.R. Jamaah)

Berdasarkan hadits di atas, dapat dipahami bahwa perintah wajib melakukan puasa ramadhan itu masih tetap berlaku bagi wanita yang haid atau nifas, hanya saja karena suatu uzur, maka kepada mereka diberikan keringanan (rukhshah) yaitu boleh tidak berpuasa pada bulan ramadhan, tetapi wajib mengqadhokannya pada hari-hari selain bulan ramadhan sebanyak puasa yang ditinggalkannya. Oleh karena itu, rukhshah atau keringanan ini terletak pada kebolehan manunda pelaksanaan puasanya, sedangkan jumlah harinya sama sekali tidak ada keringanannya; berapa hari ia meninggalkan puasa, sebanyak itu pula dia harus mengqadhokannya.

Melaksanakan kewajiban berupa qadho puasa termasuk hal yang sangat berat dibandingkan dengan melakukannya secara bersama-sama di bulan ramadhan, karena pada saat mengqadhokan puasa itu, seseorang akan berhadapan dengan berbagai cobaan dan godaan, sehingga dapat berpengaruh kepada kualitas puasa yang sedang dijalankan. Selain itu, bagi wanita yang sedang hamil berat atau sedang dalam suasana menyusukan anak juga mendapat keringanan dari syara', mereka diperbolehkan tidak berpuasa pada bulan ramadhan, sebagaimana dalam sebuah Hadits Rasulullah s.a.w. bersabda :

11 Asy-Syaukani, Nailul Author, Juz 1 (Mesir: Musthofal Al Baby Al Halabi wa auladuhu, n.d.), 328 . 
Dari Anas bin Malik Al-Ka'by, Rasulullah s.a.w. bersabda: "Sesungguhnya Allah s.w.t. telah membolehkan kepada musafir untuk tidak berpuasa dan mengurangi raka'at shalat untuknya, sebagaimana juga terhadap perempuan hamil dan menyusui dibolehkan tidak berpuasa. ${ }^{12}$ (H.R. Al-Khamsah)

Di dalam Hadits di atas, selain menjelaskan tentang uzur syara' berupa wanita hamil dan menyusui, juga tentang uzur lainnya, yaitu safar (musafir), yang semuanya akan mendapat rukhshah (keringanan), akan tetapi kewajiban yang harus dilaksanakan setelah habis masa uzur itu masih terdapat perbedaan pendapat para ulama. Hal ini desebabkan karena ayat Al-Qur'an dan Hadits tidak merinci secara tegas tentang masalah ini. Sebab, ayat Al-Qur'an dan Hadits menjelaskannya secara umum saja, sebagaimana Allah s.w.t. berfirman:

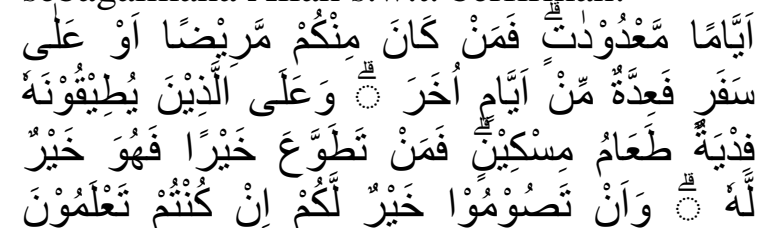

$1 \wedge \varepsilon$

(Yaitu) beberapa hari tertentu. Maka barangsiapa di antara kamu sakit atau dalam perjalanan (lalu tidak berpuasa), maka (wajib mengganti) sebanyak hari (yang dia tidak berpuasa itu) pada hari-hari yang lain. Dan bagi orang yang berat menjalankannya, wajib membayar fidyah, yaitu memberi makan seorang miskin. Tetapi barangsiapa dengan kerelaan hati mengerjakan kebajikan, maka itu lebih baik baginya, dan puasamu itu lebih baik bagimu jika kamu mengetahui. (Q.S. Al-Baqarah 184).

Meskipun ayat di atas tidak secara

${ }^{12}$ Asy-Syaukani, 258. tegas menyebutkan tentang wanita yang sedang hamil berat dan atau sedang dalam suasana menyusukan anak, namun para ulama sepakat memasukkan keduanya ke dalam kandungan ayat (orang-orang yang berat menjalankan puasa), karena di saat hamil dan menyusui wanita itu keduanya merasa berat melakukan ibadah puasa ramadhan, sehingga keduanya berhak mendapatkan fasilitas rukhshah dari Allah s.w.t.

Adapun kewajiban yang harus dilaksanakan setelah habis masa uzur masih terdapat perbedaan pendapat para ulama. Hasbi Ash-Shiddieqy mengungkapkan bahwa perempuan hamil dan menyusui wajib membayar fidyah dan tidak wajib qadho, dengan alasan bahwa kehamilan dan menyusui anak sama dengan orang sakit yang tetap dan berulang-ulang". ${ }^{13}$ Sedangkan Abdurrahman Al-Jaziri dalam mengemukakan pendapatnya berpedoman kepada pendapat para imam mazhab. ${ }^{14}$ Menurutnya, para ulama mazhab Maliki berpendapat bahwa wanita hamil dan wanita menyusui; baik wanita yang menyusui itu merupakan ibu bagi anak dari segi nasab ataupun bukan, yaitu wanita yang menyayangi anak orang lain, apabila mereka itu merasa takut akan jatuh sakit atau bertambah sakitnya jika berpuasa, baik mereka itu takut terhadap dirinya dan anaknya sekaligus, atau terhadap dirinya saja, atau terhadap anaknya saja, maka bolehlah bagi mereka tidak berpuasa tetapi mereka berkewajiban mengqadho. Mereka menambahkan bahwa wanita yang hamil tidak wajib membayar fidyah, sedangkan wanita yang menyusui berkewajiban membayar fidyah.

Para ulama mazhab Hanafi berpendapat bahwa apabila wanita hamil atau menyusui yang merasa khawatir tertimpa bahaya akibat berpuasa, mereka

13 Hasbi Ash-Shiddieqy, Pedoman Puasa (Jakarta: Bulan Bintang, 1983), 83.

14 Abdurrahman Al-Jaziri, Fiqih Empat Madzhab, Jilid 2 (Penerjemah) Moh. Zuhri Dkk. (Semarang: Asy-Syifa', 1994), 419-20. 
boleh tidak berpuasa, baik rasa khawatirnya itu terhadap dirinya saja, atau terhadap anaknya. Mereka hanya berkewajiban mengqadhokan puasa yang ditinggalkan jika ia telah mampu melakukannya dan tidak membayar fidyah serta dalam melaksanakan qadho puasa tidak harus berturut-turut.

Menurut para ulama mazhab Hambali dan Syafi'i bahwa bagi wanita yang menyusui, mereka diperbolehkan tidak berpuasa jika mereka merasa khawatir ditimpa bahaya terhadap dirinya dan anaknya. Apabila dia khawatir terhadap bahaya yang bakal menimpa dirinya dan anaknya sekaligus, atau terhadap dirinya saja, maka mereka berkewajiban mengqadhokan puasa dan tidak membayar fidyah. Sedangkan kalau mereka khawatir akan bahaya yang bakal menimpa terhadap anaknya saja, maka mereka berkewajiban mengqadhokan puasa dan wajib pula membayar fidyah.

Berdasarkan pendapat-pendapat di atas, dapat dipahami bahwa perempuan yang sedang hamil atau sedang menyusui diberikan rukhshah, karena keduanya dipandang cukup berat untuk melaksanakan puasa, sehingga para ulama memasukkannya ke dalam orang yang tidak mampu menjalankan ibadah puasa, atau dengan pertimbangan lain bahwa mereka tidak mempunyai kesempatan untuk melaksanakan kewajiban mengqadhokan puasa, yang antara lain mungkin disebabkan oleh keadaannya yang sedang mengalami uzur; atau mungkin karena mereka selalu melahirkan dalam waktu yang relatif padat.

Dewasa ini, illat hukum telah mulai bergeser, karena manusia telah dapat mengatur kehamilan dan kelahiran. Apabila tidak ada lagi kehamilan atau kelahiran, ataupun jarak kehamilan dan kelahiran pertama dan kedua cukup panjang, sehingga memberi peluang dan kesempatan bagi perempuan untuk dapat melaksanakan puasa dan atau mengqadhokannya. Oleh sebab itu, pergeseran illat itu akan merubah hukum, yaitu bagi wanita sekarang yang hamil dan menyusui, lalu dia tidak melaksanakan puasa pada bulan ramadhan, maka ia wajib membayar fidyah dan wajib pula mengqadhokannya.

Selain itu, sebagaimana diketahui bahwa usia hamil bagi seorang perempuan biasanya adalah sembilan bulan, sedangkan masa menyusui menurut ketentuan agama adalah dua tahun. Apabila seseorang perempuan hamil muda, maka dapat digolongkan seperti orang yang mengidap penyakit biasa, sehingga illat hukum untuk boleh tidak berpuasa belum begitu terasa, maka baginya lebih baik berpuasa dari pada harus mengqadhokan nantinya. Begitu pula halnya dengan perempuan yang menyusukan anak melebihi batas yang telah ditentukan oleh agama, seperti seorang perempuan yang pada tahun ketiga ia masih menyusukan anaknya, lalu pada tahun itu dia tidak melaksanakan puasa ramadhan, maka ia wajib mengqadhokan puasa yang ditinggalkan dan juga wajib membayar fidyah.

Pada umumnya, perubahan illat yang dilakukan dan diciptakan oleh manusia akan berakibat terhadap perubahan beban hukum yang kadang-kadang cendrung memberatkan. Pada sisi lain, sebahagian dari manusia kurang konsekuen dalam memahami menghayati atau melaksanakan perubahan illat tersebut. Berdasarkan hal ini, maka jelas bahwa campur tangan manusia dalam hal uzur syara' akan merubah keadaan illat hukum yang telah ada. Dan karena illatnya sudah berubah, maka akan terjadi pergeseran akibat dari hukum itu sendiri.

\section{E.Tinjuan Hukum Islam}

Sebagaimana diketahui bahwa hukum Islam yang bersumber kepada AlQur'an dan Hadits dengan segala illatnya bertujuan untuk menciptakan kemaslahatan bagi umat manusia, baik dalam bentuk mengambil manfaat maupun untuk menghindarkan mudharat. Karena itu, selaku umat Islam, maka pedoman yang dijadikan kehidupannya adalah Al- 
Qur'an dan Hadits. Adapun asas-asas hukum yang terdapat di dalam Al-Qur'an antara lain:

1. Tidak memberatkan, sebagaimana Allah s.w.t berfirman:

Dalam surat Al-Baqarah/2 ayat 286 Allah s.w.t. berfirman:

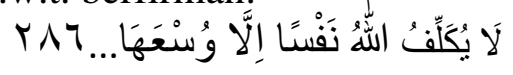

Allah tidak membebani seseorang melainkan sesuai dengan kesanggupannya. (Q.S. Al-Baqarah: 286)

Berdasarkan ayat diatas, jelaslah bahwa ajaran Islam itu sama sekali tidak memberatkan, bahkan lebih menginginkan suatu kemudahan.

2. Islam tidak memperbanyak beban atau tuntutan, maksudnya ialah semua yang ditentukan di dalam Islam, baik melalui ayat Al-Qur'an atau Hadits itu semuanya mampu dikerjakan atau dilakukan oleh manusia.

3. Ketentuan-ketentuan dalam Islam datangnya secara beransur-ansur.

Jadi hukum Islam sangat memperhatikan kemaslahatan manusia, dan ia merupakan tujuan akhir dari hukum Islam, hanya saja kadang-kadang manusia itu sendiri kurang menyadari akan hal demikian. Akibat hukum dari campur tangan manusia dalam hal uzur syara' ini, sangat bergantung kepada niat seseorang yang melakukannya. Bagi perempuan yang masih produktif, atau ditinjau dari segi usia dia masih relatif muda dan diperkirakan masih akan mengalami haid, tetapi dia menggunakan obat anti haid, dalam waktu-waktu tertentu, maka akibat hukumnya tergantung kepada niatnya. Hal ini sesuai dengan fatwa Majlis Ulama Indonesia, yang menjelaskan :

Dalam sidang Komisi Fatwa tanggal 12 Januari 1979 telah mengambil keputusan:

1. Penggunaan pil anti haid untuk kesempurnaan ibadah haji hukumnya mubah.

2. Penggunaan pil anti haid dengan maksud agar dapat mencukupi puasa Ramadhan sebulan penuh, hukumnya makruh. Tetapi bagi wanita yang sukar mengqadhokan puasanya pada hari lain, hukumnya mubah.

3. Penggunaan pil anti haid selain dari dua hal tersebut di atas, hukumnya tergantung kepada niatnya. Bila untuk perbuatan yang menjuruskan kepada pelanggaran hukum agama, hukumnya haram. ${ }^{15}$

Al-Jaziri mengungkapkan, apabila wanita menggunakan obat yang dapat memberhentikan darah haidnya bukan pada waktunya sebagaimana biasa, maka hal yang demikian itu dianggap suci, dan dengan demikian berarti ia telah habis masa iddahnya. Akan tetapi seorang wanita tidak diperbolehkan menahan keluarnya darah haid sebagaimana juga tidak boleh mempercepat keluarnya darah haid itu bila hal tersebut dapat berbahaya bagi kesehatannya, karena menjaga kesehatan hukumnya adalah wajib. ${ }^{16}$

Berdasarkan penjelasan di atas dapat dipahami bahwa hukum bagi wanita yang menggunakan pil anti haid sangat erat hubungannya dengan niat. Sedangkan niat itu sendiri terletak di dalam hati, sehingga akan sulit untuk diketahui. Namun demikian, secara tidak langsung dapat diketahui sebahagian dari niat seorang perempuan dalam menggunakan obat-obat anti haid ini, antara lain melalui sikap, atau dari gejala tingkah lakunya dan perkiraan penggunaannya dalam kehidupannya, seperti seseorang yang akan melaksanakan ibadah haji, maka penggunaan pil anti haid bertujuan agar dia dapat melaksanakan ibadah haji secara maksimal, karena ibadah haji itu sudah mempunyai alokasi waktu tertentu, sehingga bagi mereka yang sudah berada di Tanah Suci pelaksanaan hajinya tidak dapat ditunda-tunda.

Keadaan ini mungkin berlaku bagi umat Islam yang berasal dari luar Mekkah,

\footnotetext{
15 mui.or.id, "Pil Anti Haid," 2017, https://mui.or.id/produk/fatwa/757/pil-anti-haid/.

${ }^{16}$ Al-Jaziri, Fiqih Empat Madzhab, Jilid 2 (Penerjemah) Moh. Zuhri Dkk.
} 
apalagi umat Islam yang berasal dari Indonesia, karena selain tempatnya cukup jauh, juga untuk melaksanakan ibadah haji itu memerlukan dana dan tenaga yang cukup besar pula. Jadi setelah seseorang berada di Mekkah atau dalam suasana mengerjakan haji, kemudian dia mengalami haid sewaktu akan melaksanakan thawaf, maka dia tidak dibenarkan melakukan thawaf tersebut. Sebagaimana diketahui bahwa rukun haji ialah ihram, thawaf ifadhah, sya'i antara shofa dan marwa dan wuquf di Arafah. Semuanya harus dilakukan secara utuh menurut waktu yang telah ditentukan, apabila tidak dilakukan menurut waktunya, maka ibadah haji menjadi batal.

Melaksanakan haji dalam

kedudukannya sebagai ibadah disyaratkan antara lain adalah suci dari hadas besar dan kecil, sehingga bagi wanita yang mengalami haid sudah tentu tidak dibenarkan melaksanakan ibadah haji tersebut. Apabila para wanita yang berasal dari negara lain, misalnya dari Indonesia yang sudah berada di Mekkah tidak dapat melaksanakan rukun-rukun haji tersebut disebabkan mengalami haid, maka perjalanannya akan menjadi sia-sia, karena dengan tidak dibolehkan oleh agama terhadap seseorang perempuan yang sedang haid melakukan thawaf, sa'i, dan wuquf di Arafah, berarti pelaksanakan hajinya akan tertunda, dan kalau diteruskan juga pelaksanaan ibadah hajinya maka akibatnya ialah ibadah hajinya tidak sah.

Penundaan pelaksanaan ibadah haji bagi umat Islam yang berasal dari negaranegara yang jauh dari negara Arab tentu saja pada tahun berikutnya. Maka untuk melaksanakan haji pada tahun berikutnya itu membutuhkan dana dengan segala aspek pendukungnya yang relatif sama dengan keadaan yang sebelumnya. Seandainya keadaan ini betul-betul terjadi, maka akan menimbulkan kesan seolaholah pelaksanaan ajaran Islam itu cenderung memberatkan, padahal prinsip dasar atau asas umat Islam antara lain tidak memberatkan.

Bagi wanita yang berdomisili di sekitar Mekkah, mungkin tidak seberat resiko yang dialami oleh wanita-wanita yang berasal dari negara lain, karena apabila mereka mengalami haid pada musim haji tahun ini dan pelaksanaan hajinya tidak dapat dilanjutkan, maka mereka dengan mudah dapat melaksanakan mengulanginya pada tahun berikutnya. Karena itu dapat dikatakan bahwa bagi wanita-wanita yang bermuqim di Makkah akan mendapatkan fasilitas rukhshah dalam pelaksanaan ibadah haji, sebagaimana telah dijelaskan oleh Rasulullah s.a.w. dalam Hadits sebagai berikut:

Dari Ibnu Abbas r.a ia berkata: "orang yang diperintahkan agar menjadikan urusan mereka yang terakhir (dalam ibadah haji) dengan thawaf di Baitullah, tapi wanita yang haid diberikan keringanan. ${ }^{17}$ (Muttafaq Alaih)

Dari Aisyah r.a tatkala kami sampai ke Sarif (suatu tempat jauhnya 10 mil ke Makkah dari jurusan Madinah), saya berhaid. Maka Nabi s.a.w. bersabda: "lakukanlah segala yang dilakukan oleh yang berhaji, hanya tidak boleh bertawaf di Baitullah sehingga engkau suci. ${ }^{18}$ (Muttafaq Alaih)

Tetapi apabila keadaan serupa di alami oleh wanita-wanita yang berasal dari Indonesia misalnya, maka apa yang dimaksudkan oleh Hadits di atas bukanlah merupakan rukhshah, melainkan bencana atau musibah. Oleh sebab itu bagi wanitawanita, khususnya wanita yang berasal dari Indonesia yang sedang dalam suasana melaksanakan ibadah haji dibolehkan menggunakan obat atau pil anti haid tersebut, sehingga pelaksanaan ibadah hajinya tidak mengalami hambatan.

17 Sukandy, Tarjamah Bulughul Maram, 281.

${ }^{18}$ Sukandy, 58. 
Tetapi apabila penggunaan pil anti haid itu diniatkan agar dia dapat melaksanakan puasa ramadhan sebulan penuh, maka hukumnya adalah makruh. Hal ini disebabkan bahwa agama telah menyediakan keringanan bagi mereka yang mengalami uzur syara', yaitu diperbolehkan tidak melaksanakan puasa menurut waktu yang telah ditentukan, namun ia wajib mengqadhokannya pada hari lain.

Adapun pemanfaatan obat anti haid dengan niat melakukan perbuatanperbuatan yang mengarah kepada pelanggaran terhadap ketentuan agama, maka hukumnya menjadi haram. Begitu pula halnya dengan perempuan yang menggunakan obat anti hamil atau alat-alat kontrasepsi yang dapat mencegah terjadinya kehamilan atau kelahiran, maka pemakaian dan penggunaannya sangat bergantung pula kepada niat si pemakainya, sehingga dapat diketahui illat hukumnya.

Dewasa ini, penggunaan alat atau obat anti hamil sangat erat hubungannya dengan pelaksanaan Keluarga Berencana (KB), karena itu hukum melaksanakan KB tidak terlepas dari niat atau motivasinya. Ada beberapa pendapat tentang masalah ini:

Masyfuk Zuhdi menyatakan kalau seorang Muslim melaksanakan KB dengan motivasi yang hanya bersifat pribadi, misalnya ber-KB untuk menjarangkan kehamilan/ kelahiran, atau untuk menjaga kesehatan/kesegaran/ kelangsingan badan si ibu, hukumnya boleh saja. ${ }^{19}$ Tetapi hukum ber-KB bisa menjadi makruh bagi pasangan suami istri yang tidak menghendaki kehamilan si istri, padahal suami istri tersebut tidak mengalami hambatan/ kelainan untuk mempunyai keturunan. Sebab hal yang demikian itu bertentangan dengan tujuan perkawinan menurut agama.

${ }^{19}$ Masyfuk Zuhdi, Masail Fiqhiyah (Jakarta: CV. Haji Masagung, 1989), 52.
Hukum ber-KB juga menjadi haram (berdosa), apabila orang melaksanakan $\mathrm{KB}$ dengan cara yang bertentangan dengan norma agama. Misalnya dengan cara vasektomi (sterilisasi suami) dan abortus (pengguguran). ${ }^{20}$

Muhammadiyah menyatakan bahwa boleh melakukan penjarakan dan penundaan kehamilan dalam mengikuti KB dengan dasar sebagai berikut:

a. Mengkhawatirkan keselamatan jiwa atau kesehatan ibu karena mengandung atau melahirkan, bila hal itu diketahui dengan pengalaman atau keterangan dokter yang dapat dipercaya.

b. Mengkhawatirkn keselamatan agama, akibat faktor-faktor kesempitan hidup.

c. Mengkhawatirkan kesehatan atau pendidikan anak-anak bila jarak kelahiran terlalu dekat. ${ }^{21}$

Menurut Ulama Hisbab Persis dalam sidangnya yang ke-8 di Ciganitri Bandung, memutuskan:

a. Keluarga Berencana (KB) dalam pengertian "pengaturan jarak kelahiran" hukumnya ibahah, dan tidak dilarang

b. Keluarga Berencana (KB) dalam pengertian "pembatasan jumlah kelahiran" hukumnya haram, dan dilarang oleh syari'at agama.

c. Mengikuti program KB karena takut kelaparan, hukumnya juga haram.

d. Cara-cara KB yang dapat ditempuh adalah azal, pantang berkala, cream jelly, vaginal tablet, pil, suntikan, AKBK, dan

${ }^{20}$ Zuhdi, 54. Himpunan Putusan Tarjih (Yogyakarta: PP Muhammadiyah, n.d.), 309; Fathurrahman Djamil, Metode Ijtihad Majlis Tarjih Muhammadiyah (Jakarta: Logos Wacana Ilmu, 1995), 85. 
sebagainya $^{22}$.

Menurut Mahmoud Syaltut, bahwa: "program KB itu dimaksudkan sebagai usaha pembatasan anak dalam jumlah tertentu, misalnya hanya 3 anak untuk setiap keluarga dalam segala situasi dan kondisi tanpa kecuali, maka hal tersebut bertentangan dengan syari'at Islam". ${ }^{23}$ Selain cara-cara tersebut di atas, dikenal pula adanya cara atau alat klontrasepsi seperti IUD dan sejenisnya, yang di dalam musyawarah Ulama terbatas mengenai KB di pandang dari segi hukum syari'at Islam pada tanggal 26 s/d 29 juni 1972 memutuskan antara lain bahwa:

Pemakaian IUD dan sejenisnya tidak dapat dibenarkan selama masih ada obat-obat dan alat-alat lain, karena untuk pemasangannya/ pengontrolanya harus dilakukan dengan melihat aurat besar (mughallazhoh) wanita; dimana diharamkan oleh syari'at Islam. ${ }^{24}$

Dewasa ini ada efek dari penggunaan alat kontrasepsi seperti suntik, dimana perempuan tersebut akan mengalami masa haid secara terus menerus dan lebih lama dari masa yang biasanya, kadang-kadang mencapai satu bulan atau lebih. Menurut Hanabilah dan Syafi'iyah haid itu mempunyai batas awal dan batas akhir. Adapun batas minimal masa haid adalah sehari semalam, dengan syarat darahnya itu keluar seperti, biasanya pada masa haid, dimana apabila ia meletakan sepotong kapas maka kapas itu akan berlumur darah. ${ }^{25}$

${ }^{22}$ Putusan Sidang Hisbah Peiode Ke-8, pada tanggal 28 Nopember 1993, di Ciganitri, Bandung. Dede Rosyada, Metode Kajian Hukum Dewan Hisbab Persis (Jakarta: PT. Logis Wacana Ilmu, 1999), 156.

${ }^{23}$ Zuhdi, Masail Fiqhiyah, 51.

${ }^{24}$ Zuhdi, 69.

${ }^{25}$ Yang dimaksud dengan sehari semalam adalah dua puluh empat jam, di mana apabila wanita itu melihat darah pada dirinya kemudian darah itu berhenti sebelum batas waktunya
Sementara batas maksimal Al-Jaziri menyebutkan masa haid adalah lima belas hari (lima belas malam). Maka apabila ia masih melihat darah setelah habisnya batas waktu itu berarti darah yang keluar itu bukanlah darah haid. Dalam ketentuan batas ini tidak perlu memperhatikan kebiasaan seorang wanita. Bila ada seorang wanita yang biasa mengeluarkan darah haidnya selama tiga hari saja, atau empat hari, atau lima hari dan seterusnya, kemudian kebiasaannya itu berubah lalu ia melihat darah setelah hari berikutnya, maka ia dianggap sebagai haid hingga mencapai lima belas hari.

Ulama Hanafiyah berpendapat batas minimal masa haid adalah tiga hari tiga malam. Sedangkan batas maksimal adalah sepuluh hari sepuluh malam. Jika wanita itu mempunyai kebiasaan tersendiri, lalu ia mengalami haid lebih dari batas sebagaimana biasanya-dalam artian masih tetap di bawah sepuluh hari- maka selebihnya itu diangap sebagai darah haid. Misalnya ia biasa mengalami masa haid selama tiga hari. Kemudian ia melihat adanya darah selama empat hari, maka kebiasaannya itu berubah menjadi empat hari; dan darah pada hari keempat itu dianggap sebagai darah haid, karena kebiasaan itu tetap berlaku baginya walaupun hanya sekali mengalami. Jika kebiasaan yang ia alami adalah empat hari, kemudian ia melihat adanya darah itu selama lima hari, maka berarti kebiasaannya berubah menjadi lima hari, dan darah pada hari kelima itu dianggap sebagai darah haid. Begitulah seterusnya hingga sampai pada batas waktu sepuluh hari. Sedangkan apabila keluarnya darah itu melebihi batas sepuluh hari, maka darah tersebut dinamakan darah istihadhah, bukan darah haid. Bahkan ia

berlalu, maka ia tidak dianggap sebagai wanita haid. Dalam hal ini tidak disyaratkan ia melihat darah haid itu pada awal siang dan berlangsung terus sepanjang siang dan malam, akan tetapi ukuran tersebut bergantung kepada lewatnya dua puluh empat jam dari awal pertama darahnya keluar. Al-Jaziri, Fiqih Empat Madzhab, Jilid 2 (Penerjemah) Moh. Zuhri Dkk., 281. 
itu dikembalikan kepada kebiasaan yang ia alami. Maka masa haidnya ditentukan sesuai dengan masa kebiasaan wanita itu mengalami haid. Dan selebihnya dari kebiasaan itu disebut darah istihadhah.

Ulama Malikiyah berpendapat bahwa haid dalam kaitannya dengan ibadah tidak ada batas minimalnya, baik dilihat dari segi darah yang keluar atau dilihat dari segi masa keluarnya darah tersebut. Jika darah itu telah keluar walaupun hanya sekali dan sekejap, maka ia dianggap haid. Sedangkan haid dalam kaitannya dengan 'iddah dan istibra' maka ketentuan waktu sedikitnya adalah sehari penuh atau sebagian dari padanya.

Begitu pula tidak ada batas paling banyaknya bila dilihat dari segi darah yang keluar. Oleh karena itu, tidaklah ditentukan dengan banyak satu kali, misalnya, atau lebih dari itu, atau mungkin juga kurang. Sedangkan batas maksimalnya dilihat dari segi masa haid maka ditentukan selama lima belas hari bagi wanita pemula yang bukan hamil. Dan tambah tiga hari lagi dari kebiasaan masa haid yang lebih sering ia alami untuk memperjelasnya. Jika ia biasa mengalami masa haid lima hari, kemudian darah haidnya habis, maka hendaknya wanita itu menunggu hingga delapan hari. Dan jika ternyata darahnya masih keluar pada masa haid yang ketiga, berarti kebiasaan wanita tersebut adalah delapan hari karena kebiasaan itu menjadi tetap karena sekali mengalami, dan hendaknya ia menunggu hingga sebelas hari. Dan jika darah haid itu terus keluar pada masa haid yang keempat, maka hendaknya wanita itu menunggu hingga empat belas hari. Jika darah haidnya itu masih keluar setelah itu, maka seorang wanita itu tidaklah mengalami masa haidnya lebih dari lima belas hari, dan darah yang keluar setelah lima belas hari atau setelah menunggu selama tiga hari untuk memperjelasnya sesuai dengan kebiasaan masa haid yang lebih sering ia alami sebelum mencapai lima belas hari maka darah itu disebut darah istihadhah.
Di sisi lain perempuan sekarang bisa mengalami haid selama sebulan secara terus menerus dampak penggunaan pil haid dan suntik untuk menghentikan haid. Pada saat suntik untuk yang tiga bulan maka selama dua bulan pertama perempuan tersebut tidak haid tetapi setelah masuk bulan ketiga dia mengalami haid yang lama. Padahal batas maksimal yang ditetapkan oleh semua Imam empat mazdhab itu adalah 15 hari.

Penetapan batas maksimal 15 hari masa haid oleh Imam empat madzhab itu apabila tidak ada campur tangan manusia, tetapi untuk kasus suntik tiga bulan ini ada campur tangan manusia sehingga mengakibatkan illat hukumnya pun berubah dimana batas maksimal perempuan dalam haid bisa bertambah melebihi batas maksimal yang ditentukan oleh ulama, dengan melihat warna darah dan volume yang keluar dari perempuan tersebut.

Darah haid itu menurut ulama Malikiyah darah yang keluar berwarna merah murni, atau kuning atau berwarnaa keruh yaitu antara warna hitam dan putih, walaupun pada hakikatnya darah itu adalah yang khusus berwarna merah murni. Ini adalah pendapat yang terkenal dalam madzhab Malikiyah. Dan seandainya dari kubul wanita dalam usia yang cukup untuk haid keluar air berwarna kuning ataupun air berwarna keruh, maka wanita itu berarti haid, sebagaimana apabila ia melihat darah berwarna merah pada dirinya. Sebagian dari mereka mengatakan bahwa darah haid itu berwarna merah. Sedangkan yang berwarna kuning atau keruh, maka hal itu sama sekali bukanlah disebut dengan darah haid. Sebagian dari mereka mengatakan baik berwarna kuning atau pun berwarna keruh, bila ia keluar pada masa haid, berarti yang keluar itu adalah darah haid. Dan jika keluar bukan pada masa haid, maka tidak disebut darah haid. Sebagian dari pendukung madzhab ini mengatakan, bahwa pendapat ini adalah yang paling benar (menurutnya) di antara pendapatpendapat lain yang telah disebutkan. 
Menurut ulama Hanafiyah yang dimaksud dengan "darah", hal itu meliputi semua darah yang enam: merah, keruh, hijau, abu-abu, kuning, dan hitam. Apabila dari dalam rahim seorang wanita keluar (darah) yang mempunyai salah satu dari sifat tersebut, maka itu disebut darah haid, dengan syarat darah tersebut keluar ke bagian luar kubul perempuan.

Menurut Syafi'iyah yaitu yang termasuk kategori dari kelima warna darah sebagaimana berikut:

a. Warna hitam, inilah darah yang paling kental menurut mereka. Setelah warna ini barulah tingkatan warna berikut ini:

b. Warna merah.

c. Warna kuning kemerah-merahan (pirang).

d. Warna keruh.

e. Warna kuning. warna ini adalah tingkatan warna setelah warna keruh dan dikatakan pula bahwa warna kuning ini lebih tingkatannya dari pada warna keruh.

Apabila darah yang keluar termasuk kategori darah yang enam itu yaitu merah, keruh, hijau, abu-abu, kuning, dan hitam maka itu adalah darah haid. Untuk mereka yang telah ada uzur syara'nya maka batas maksimal haidnya tergantung dari darah yang keluar itu tanpa ada batas maksimalnya, karena mereka pada dua bulan yang sebelumnya tidak haid, dan haid pada bulan ketiga yang lama. Untuk volume darah haid itu, adalah apabila sudah keluar dari kubul tapi kalau hanya sebatas flek maka itu dinamakan darah istihadhah.

Berdasarkan kutipan di atas, jelaslah bahwa dengan adanya campur tangan manusia dalam hal uzur syara', maka akan terjadi perubahan illat hukum, dan dengan sendirinya pula hukumpun akan berubah pula. Perubahan hukum itu sangat bergantung kepada niat dan motivasi, namun selagi campur tangan manusia tersebut uzur syara' lebih mengarahkan kepada hal yang positif, maka agama dapat membenarkannya, tetapi apabila mengarah kepada pelanggaran ketentuan agama, maka sama sekali tidak dapat dibenarkan, dan hukumnya menjadi haram.

\section{F. Penutup}

Perempuan yang sedang haid dan hamil atau sedang menyusui diberikan rukhshah, karena keduanya dipandang cukup berat untuk melaksanakan puasa, sehingga para ulama memasukkannya ke dalam orang yang tidak mampu menjalankan ibadah puasa, atau dengan pertimbangan lain bahwa mereka tidak mempunyai kesempatan untuk melaksanakan kewajiban mengqadhokan puasa, yang antara lain mungkin disebabkan oleh keadaannya yang sedang mengalami uzur. Perubahan illat hukum bergeser karena manusia telah dapat mengatur kehamilan dan kelahiran. Perubahan illat yang dilakukan dan diciptakan oleh manusia akan berakibat terhadap perubahan beban hukum yang kadang-kadang cendrung memberatkan manusia sendiri. Pada sisi lain, sebahagian dari manusia kurang konsekuen dalam memahami menghayati atau melaksanakan perubahan illat tersebut.

Namun pada dasarnya dapat dipahami bahwa hukum bagi wanita yang menggunakan pil anti haid sangat erat hubungannya dengan niat. Sedangkan niat itu sendiri terletak di dalam hati, sehingga akan sulit untuk diketahui. Secara tidak langsung dapat diketahui sebahagian dari niat seorang perempuan dalam menggunakan obat-obat anti haid ini, antara lain melalui sikap, atau dari gejala tingkah lakunya dan perkiraan penggunaannya dalam kehidupannya, seperti seseorang yang akan melaksanakan ibadah haji, maka penggunaan pil anti haid bertujuan agar dia dapat melaksanakan ibadah haji secara maksimal, karena ibadah haji itu sudah mempunyai alokasi waktu tertentu, sehingga bagi mereka yang sudah berada di Tanah Suci pelaksanaan hajinya tidak dapat ditunda-tunda. 


\section{Daftar Pustaka}

Al-Jaziri, Abdurrahman. Fiqih Empat Madzhab, Jilid 2 (Penerjemah) Moh. Zuhri Dkk. Semarang: Asy-Syifa', 1994.

Ash-Shiddieqy, Hasbi. Pedoman Puasa. Jakarta: Bulan Bintang, 1983.

Asy-Syaukani. Nailul Author, Juz 1. Mesir: Musthofal Al Baby Al Halabi wa auladuhu, n.d.

Azhari, Fathurahman. "Pemikiran Ulama Tentang 'Illat Hukum (Suatu Kajian Ushul Fiqh)." Jurnal Darussalam 15, no. 2 (2014): 35-52. http://idr.uinantasari.ac.id/6808/.

Bahar, Muchlis. "Metode Penemuan Alasan Rasional Dalam Hukum Islam (Masalik Al-'Illat)." FITRAH: Jurnal Kajian Ilmu-Ilmu Keislaman 1, no. 1 (May 31, 2015): 177-88. https://doi.org/10.24952/fitrah.v1i1.3 34.

Caniago, Sulastri. "Azimah Dan Rukhshah Suatu Kajian Dalam Hukum Islam." Juris 13, no. 2 (2014): 115-25. https://doi.org/10.1234/juris.v13i2.11 37.

Djamil, Fathurrahman. Metode Ijtihad Majlis Tarjih Muhammadiyah. Jakarta: Logos Wacana Ilmu, 1995.

Harisudin, Noor. Pengantar Ilmu Fiqh. Surabaya: CV. Salsabila Putra Pratama, 2019.

Miles, Matthew B., A. Michael Huberman, and Johnny Saldaña. Qualitative Data Analysis: A Methods Sourcebook. California: SAGE Publications, Inc., 2014.

mui.or.id. "Pil Anti Haid," 2017. https://mui.or.id/produk/fatwa/757/pil -anti-haid/.

Pengurus Pusat Muhammadiyah. Himpunan Putusan Tarjih. Yogyakarta: PP Muhammadiyah, n.d.

Romli. "Illat Dan Pengembangan Hukum Islam." Intizar 20, no. 2 (2014): 22146.

http://jurnal.radenfatah.ac.id/index.ph p/intizar/article/view/431.

Rosyada, Dede. Metode Kajian Hukum
Dewan Hisbab Persis. Jakarta: PT. Logis Wacana Ilmu, 1999.

Rouf, Abd. "Model Ijtihad Ulama Di Era Modern." Sakina: Journal of Family Studies 3, no. 1 (2019): 1-12. http://urj.uinmalang.ac.id/index.php/jfs/article/vie w/428.

Sodiqin, Ali. "Fiqh Sains: Elaborasi Konsep 'Illat Menuju Pembentukan Hukum Islam Yang Aktual." $A l$ Mazaahib (Jurnal Perbandingan Hukum) 1, no. 1 (2012): 1-16. http://ejournal.uinsuka.ac.id/syariah/almazahib/article/v iew/1338.

Sukandy, Muh. Syarief. Tarjamah Bulughul Maram. Bandung: AlMa'arif, 1991.

Syah dkk., Ismail Muhammad. Filsafat Hukum Islam. Jakarta: Bumi Aksara, 1992.

Ubaidillah, Ubaidillah. "Konspirasi Politik' Hukum Islam Di Indonesia." Mahkamah: Jurnal Kajian Hukum Islam 3, no. 2 (2018): 219-26. https://doi.org/10.24235/mahkamah.v $3 \mathrm{i} 2.3414$.

Yahya, Mukhtar. Dasar-Dasar Pembinaan Hukum Islam. Bandung: Al-Ma'arif, 1993.

Zuhdi, Masyfuk. Masail Fiqhiyah. Jakarta: CV. Haji Masagung, 1989. 